\title{
Uterovaginal prolapse with myiasis: a case report
}

\author{
Ananthi Kasinathan*, N. Fatima Shanthini
}

Department of Obstetrics and Gynaecology, Sri Manakula Vinayagar Medical College and Hospital, Madagadipet605107, Pondicherry, India

Received: 11 April 2014

Accepted: 3 May 2014

\section{*Correspondence:}

Dr. Ananthi Kasinathan,

E-mail: srivatsanray@yahoo.com

(C) 2014 Kasinathan A et al. This is an open-access article distributed under the terms of the Creative Commons Attribution Non-Commercial License, which permits unrestricted non-commercial use, distribution, and reproduction in any medium, provided the original work is properly cited.

\section{ABSTRACT}

Myiasis is the infestation of the tissues of vertebrate animals by the larvae of flies. Genital myiasis is a rare condition, as it commonly presents as mucocutaneous form. We present a case of 80 year old lady with third degree uterovaginal prolapse and maggot infestation of an ulcer over the posterior aspect of the prolapse.

Keywords: Myiasis, Postmenopausal, Uterovaginal prolapse

\section{INTRODUCTION}

Myiasis is derived from the Greek word "myia" meaning fly. ${ }^{1,2}$ Dipterous larvae (maggots) feeding on the host's dead or living tissue, liquid body substances or ingested food is defined as myiasis. It causes massive tissue infection, severe inflammatory reaction and secondary bacterial infection. Our patient had third degree uterovaginal prolapse with a large benign ulcer over the posterior surface of the prolapsed mass which was infested with maggots. Very few such cases have been reported in literature.

\section{CASE REPORT}

An eighty year old postmenopausal lady presented to our op with complaints of mass descending per vagina for 2 years. Initially it was reducible, now for the past 6 months it had become irreducible and she had difficulty in micturition and had constipation. She was suffering from bronchial asthma for the past ten years.

On examination she was unhygienic, general condition was poor. She was pale, there was no lymphadenopathy. Her abdomen was soft. Local examination showed atrophic external genitalia. Cervix was lying $8 \mathrm{~cm}$ outside the introitus with large cystocoele and large rectocoele.
Over the posterior vaginal wall, about $4 \mathrm{~cm}$ from the external os, there was a $5 \times 5 \mathrm{~cm}$ ulcerated area with multiple pores/holes in it. Through them multiple maggots were seen coming out (Figure1). The prolapse was irreducible.

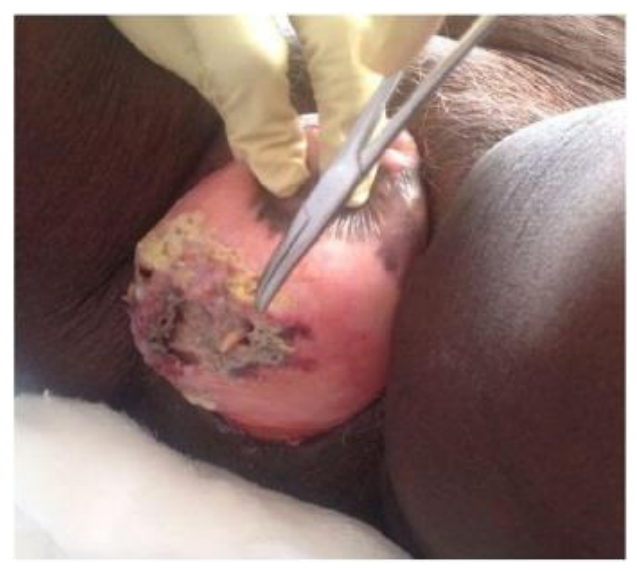

Figure 1: Ulcer over the posterior wall of the prolapse with artery forceps pointing towards the maggot.

Turpentine was applied to the ulcerated area and the worms were removed. Biopsy was taken from the margin of the ulcerated region and sent for HPE. 


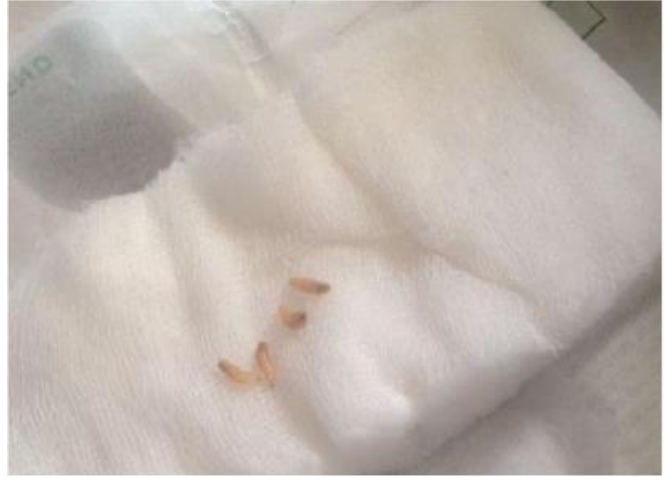

Figure 2: Extracted maggot.

This was reported as chronic ectocervicitis with procidential changes, with no evidence of malignancy. Daily dressing was done to reduce the congestion. Concurrently antibiotics were started. The ulcer healed, the prolapse was finally reduced and a ring pessary was inserted.

\section{DISCUSSION}

Our patient was an agricultural labourer, belonged to low socioeconomic status and had poor personal hygiene. Due to old age, she was less active. These were the main contributing factors in the development of myiasis in the prolapse.

Similar case of genital myiasis has been reported in a ulcerated prolapsed uterus where the ulcer healed well with treatment. ${ }^{3}$ There is also a report of associated squamous cell carcinoma of cervix. ${ }^{4}$ This had presented as a necrotic ulcerated area in the prolapse which was infested with maggots.

In another case report, the patient presented with vaginal carcinoma with myiasis and irreducible procidentia. ${ }^{5}$ Total genital prolapse with superinfected uterine myiasis has also been reported. ${ }^{6-8}$

The ulcer in our patient was not malignant. Probably the ulcer had developed due to friction or congestion due to chronic exposure to external environment. Over this, maggot infestation had developed. Turpentine created an anaerobic environment which caused the maggots to wriggle out. ${ }^{9}$ Saldarriaga et al. described for the first time the use ivermectin to treat myiasis successfully. In this patient, the ulcer healed well with oral antibiotics and local gentamycin cream application. With improvement in personal hygiene and good nutrition, our patient's general condition improved as did the ulcer. This enabled us to reposit the prolapse within the vagina and place ring pessary.

\section{Funding: No funding sources \\ Conflict of interest: None declared \\ Ethical approval: Not required}

\section{REFERENCES}

1. Hope FW. On insects and their larvae occasionally found in the human body. Trans $\mathrm{R}$ Entomol Soc Lond. 1840;2:256-71.

2. Burns DA. Diseases caused by arthropods and other noxious animals. In: Burns T, Breathnach S, Cox N, Griffiths C, eds. Rook's Textbook of Dermatology. 7th ed. Malden, MA: Blackwell Publishing; 2004: 33.8-33.11.

3. Ray Sabyasachi, Basak Subhadeep, Konar Hiralal. Maggots in prolapsed uterus-polluted progress of lifestyle. Med J Armed Forces India. 2012;68(3):240-1.

4. Dhakne P, Gupta AS. Genital myiasis. J Postgrad Gynaecol Obstet. 2014;1(1):13-6.

5. Baidya J. A rare case of genital myiasis in a woman with genital prolapse and malignancy and review of literature. Ann Trop Med Pub Health. 2009;2:29-30.

6. Saldarriaga W, Herrera E, Castro D. Myiasis in uterine prolapsed, successful treatment. Am J Obstet Gynaecol. 2011;205(3):e5-6.

7. Lopes-Costa PV, Pereira-Filho JD, da Silva BB. Myiasis in the uterine cavity of an elderly woman with a complete uterine prolapse. Trans R Soc Trop Med Hyg. 2008 Oct;102(10):1058-60.

8. Shaunik A. Pelvic organ myiasis. Obstet Gynaecol 2006 Feb;107(2 Pt 2):501-3.

9. Fabio Francesconi, Omar Lupi. Myiasis. Clin Microbiol Rev. 2012 Jan;25(1):79-105.

DOI: $10.5455 / 2320-1770 . i j \mathrm{rcog} 20140643$

Cite this article as: Kasinathan A, Shanthini NF.

Uterovaginal prolapse with myiasis: a case report. Int J Reprod Contracept Obstet Gynecol 2014;3:477-8. 